International Journal of Education (IJE) Vol.6, No.4, December 2018

\title{
EFFECT OF TEACHING APPROACHES IN STEM CAREER ORIENTATION FOR STUDENTS THROUGH BIOLOGY LEARNING IN VIETNAM
}

\author{
Ho Thi Hong Van ${ }^{1}$ and Le Ngoc Hoan ${ }^{2}$ and Dinh Quang Bao ${ }^{2}$ \\ ${ }^{1}$ The Vietnam National Institute of Educational Sciences, Vietnam \\ ${ }^{2}$ Hanoi National University of Education, Vietnam
}

\begin{abstract}
This study investigated the association between teaching approaches in Biology and STEM career aspiration of upper secondary school students and how to apply in learning and teaching. In this research, we analyzed some teaching approaches in Biology which would actively improve students' subject interest as well as their STEM career aspiration in upper secondary schools in Hanoi and some Northern provinces of Vietnam and supposed suggestions for teachers use in their teaching approaches and teaching methods to promote the effectiveness of science-oriented teaching in their lectures. Analysis of science learning in Vietnam in this study highlighted that teaching the 'applications of science' and teaching 'the relevance of study and career' were measured teaching approaches to consistently and positively associated with upper secondary school students' STEM career aspiration, accounting for other teaching approaches. Additionally, in this study, the 'student-led investigations' indirectly associated with students' STEM career aspiration by affecting on affected student's career awareness and student's science self-efficacy. However, the project-based approach had no obvious effect on students' STEM career aspiration.
\end{abstract}

\section{KEYWORDS:}

Biology learning, STEM, Career orientation teaching, Teaching approach

\section{INTRODUCTION}

Upper secondary school is a significant period for students in science and affects their future career decisions (Subotnik, R.F., 2010). Therefore, learning science (such as Biology, Chemistry, Physics) at the high school is a necessary base for further study in term of science in the university which is essential for having a career in the field of science and STEM (Science, Technology, Engineering, Mathematics). It is believed that experience activities at a school play a particularly important role in enabling students to select future careers in the field of science (Sheldrake, 2017). Another study showed that secondary education was indeed an important time to develop students' interest in science (Maltese, Melki, \& Wiebke, 2014) and the interest of students in science and applied science. The scientific awareness of students is believed to be associated with their academic aspirations and career orientation (Regan \& DeWitt, 2015). The aspirations of students in science courses in upper secondary school actually predicted whether they would have earned a degree related to science at university (Malta \& Tai, 2011; Gelbgiser, \& Weeden, 2013; Tai, Qi Liu, Maltese, \& Fan, 2006). Therefore, teachers' teaching approaches and learning activities in teaching Biology are designed to promote student attitudes such as interest 
International Journal of Education (IJE) Vol.6, No.4, December 2018

in science and thereby promote STEM-related career aspirations. It is especially important to use specific teaching methods such as using real work experience or project-based activities and exploring the relevance of Biology school subject and STEM career because they may enhance students' interest and their career aspiration in the future.

\section{THE ORETICAL BACKGROUND}

Recent research indicated that science teachers play an increasingly important role in encouraging students to explore the links between science and the professional field (Cohen \& Patterson, 2012). Although students do not have access to career educators, every upper secondary school student is exposed to at least one science teacher such as Biology teacher, chemistry teacher or physics teacher. Therefore, providing career information and connecting students with career opportunities related to STEM when teaching science such as Biology will be important to students. The definition of occupation in the STEM field is growing rapidly, especially with the industry 4.0, making it necessary for teachers to regularly update future career descriptions and the new skills needed to enter these areas.

By literature reviewing, various measures have been taken to promote student attitudes towards science (Rosenzweig \& Wig, 2016). Many teaching approaches have been adopted to improve students' interest in science subjects, such as highlighting the link between scientific knowledge and explaining the experience and work of scientists (Bernacki, Nokes-Malach, Richey, \& Belenky, 2016; Hong \& Lin-Siegler, 2012; Hulleman \& Harackiewicz, 2009). Similarly, promoting the relevance and practical application of science to students and parents has been linked to excitement, improved student performance (Harackiewicz, Rozek, Hulleman, \& Hyde, 2012; Rozek, Hyde, Svoboda, Hulleman and Harackiewicz, 2015). Overall, teachers can explain broader scientific or scientific occupations in a variety of ways, using the methods of active learning and teaching.

\section{Project-based activities}

Project-based activities and practical work are still valuable in teaching science. For example, through practical work simulated to reaffirm the experimental nature of science are possible (Abrahams \& Reiss, 2012; Hodson, 1993; Millar, 1998). Behavioural assessment data have hypothesized that students have a more positive attitude toward science when the teacher regularly emphasizes practical practices and as the student progresses. Project-based activities and practical work have created a more positive attitude for students. This is claimed to be effective when students are given the opportunity to create independent hypotheses and draw their own conclusions (Ornstein, 2006).

\section{Student-led investigation approach}

Science teaching focuses on student-led activities rather than teacher-led activities (but with some guidance and support from teachers), usually is through observation and experimentation (and may be similar to actual work) and this is an opportunity for students to apply more scientific methods (Dano-Hinosolango, 2013; Furtak, Seidel, Iverson, \& Briggs, 2012; Minner, Levy, \& Century, 2010; Schroeder, Scott, Tolson, Huang, \& Lee, 2007). 
International Journal of Education (IJE) Vol.6, No.4, December 2018

\section{Teaching relevance of study and career}

These are the approaches applied in teaching science when the context of teaching science is used as the starting point for the development of scientific ideas (Bennet, 2006). This is in contrast to traditional approaches in the formulation of scientific ideas before, then new applications. Teaching the relevance of study and career focuses more on enhancing the interest in the subject, and the relevance of subject knowledge to the application of life and career, through the use of contexts that apply scientific skills and ideas (Bennett, Lubben, \& Hogarth, 2007).

\section{Science application teaching}

Teaching science application is teaching the broader application of the lesson knowledge and the relevance of scientific knowledge in the lesson to the life of the student) is the only teaching method that is measured consistently and positively compared to other teaching methods (R. Sheldrake et al., 2017).

In Vietnam, the experience of solving a practical work in STEM careers has not been elucidated yet.

\section{RESEARCH OBJECTIVES, RESEARCH QUESTIONS AND HyPOTHESIS}

The action study aims (1) to investigate which teaching approaches in Biology teaching will actively support the STEM occupational orientation in upper secondary schools in Hanoi and some Northern provinces of Vietnam and (2) recommend for teachers use in their teaching strategies and teaching methods to promote the effectiveness of STEM career orientation teaching in their lectures.

The research question is: Which Biology learning activities and teaching strategies promote students' subject interest and students' STEM career orientation in Vietnam?

Additionally, this study tested the following hypotheses to address the research question:

H1a: Teaching method of student-led investigation activities contribute to students' career awareness.

H1b: Teaching method of student-led investigations activities contribute to students' science selfefficacy.

H2a: Teaching about the application of science contributes to students' utility of science.

H2a: Teaching about the application of science contributes to students' career awareness.

H3: Teaching method of project-based activities contributes to students' science self-efficacy.

H4a: Teaching of the relevance of study and career contributes to students' utility of science.

H4b: Teaching of the relevance of study and career contributes to students' science self-efficacy.

$\mathrm{H} 4 \mathrm{c}$ : Teaching of the relevance of study and career contributes to students' subject interest.

H5: Students' subject interest contributes to students' science-related career aspiration.

H6: Students' career awareness contributes to students' science-related career aspiration.

H7a: Students' science self-efficacy contributes to students' science-related career aspiration.

H8: Students' subject interest contributes to students' science-related career aspiration. 


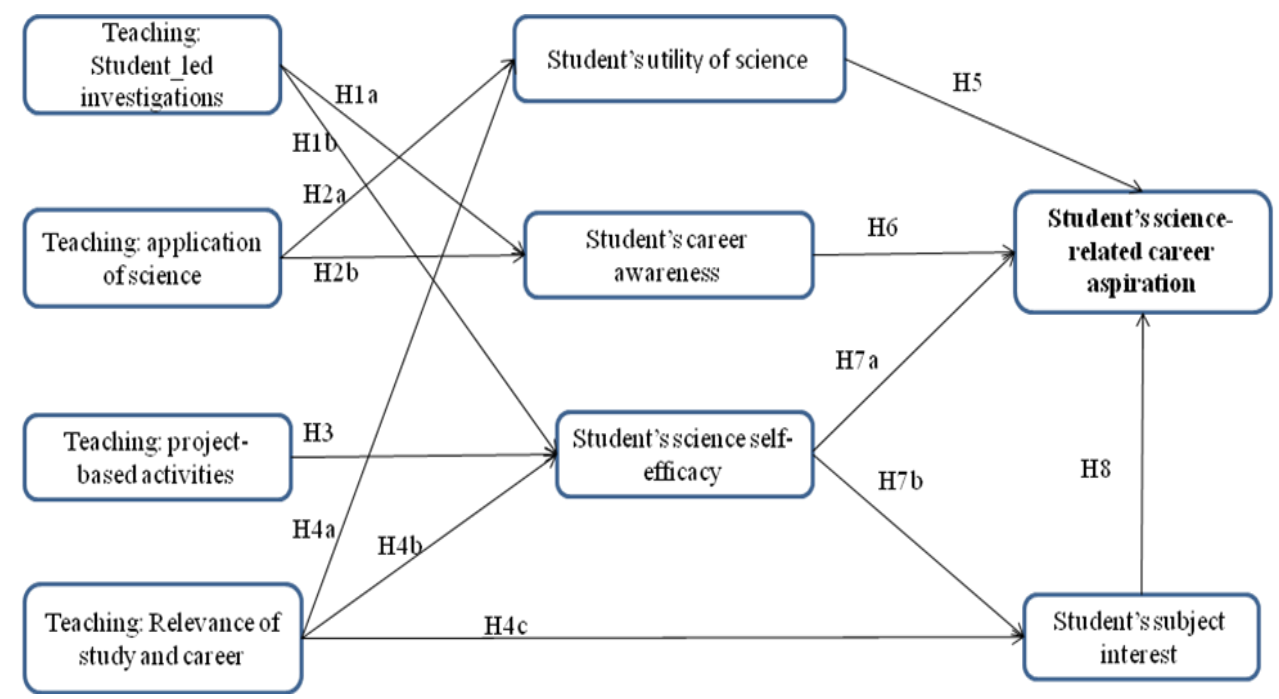

Figure1. Research framework

\section{RESEARCH METHODOLOGY}

\subsection{Research Instruments}

Questionnaires are manipulated from previous research (Novodvorsky, 1993; Stake, J.E., \& Mares, K.R., 2001; Ornstein, 2005; OECD, 2015) and adapted to the context of the study. Then, the understandability of the questions was evaluated by the accession and suggestion of the 30 students in Hanoi Experimental Upper Secondary School, Hanoi, Vietnam.

The items/factors of the questionnaire were scaled by using Likert-scales. Specifically, the frequency of doing learning activities with different teaching approaches of students was from (1) 'Never or hardly ever', (2) 'In some lessons', (3) 'In most lessons', to (4) 'In all lessons'. Moreover, the scales of consent on the statements about career application and Biology interest of students were from (1) 'Strongly disagree', (2) 'Disagree', (3) 'Agree', (4) 'Strongly agree'. Some examples of items/factors in the questionnaires are described in Table 1.

Table 1. Some examples of items/factors in the questionnaires

\begin{tabular}{|l|l|}
\hline Item/factor & Example item \\
\hline Career orientation & "Students learn about professions related to subject area" \\
\hline $\begin{array}{l}\text { Teaching: project-based } \\
\text { activities }\end{array}$ & $\begin{array}{l}\text { 'Students are asked to draw conclusions from an } \\
\text { experiment they have taken" }\end{array}$ \\
\hline $\begin{array}{l}\text { Teaching: applications of } \\
\text { science }\end{array}$ & "I discuss questions of practical relevance" \\
\hline $\begin{array}{l}\text { Teaching: student-led } \\
\text { investigation activities }\end{array}$ & $\begin{array}{l}\text { "Students are given the chance to choose their own } \\
\text { investigations" }\end{array}$ \\
\hline Students seft-efficacy & $\begin{array}{l}\text { "Describe the role of antibiotics in the treatment of } \\
\text { disease" }\end{array}$ \\
\hline Students' subject interest & "I enjoy acquiring new knowledge in Biology" \\
\hline
\end{tabular}




\subsection{Data collection}

The survey was conducted with 345 students in grade 10 (at the age of 16). Investigation is conducted by direct investigation. Direct surveys use contact methods and students interviews at 6 upper secondary schools in Hanoi and some northern provinces of Vietnam such as Nam Dinh, Vinh Phuc province. We distributed 350 questionnaires directly collected 345 validated questionnaires. The total number of questionnaires for the official analysis is 345 , which is greater than 200 according to the study of Comrey and Lee (1992).

\subsection{Data Analysis}

Data were collected through a questionnaire and analyzed by using the descriptive and regression analysis. Factors and dependent variables in the model were tested for reliability of the scale by Cronbach's $\alpha$ coefficient and coefficient of correlation. To see the questionnaire in the current study, Cronbach's $\alpha$ was used and the questionnaire was tested on other participants outside the real participants. One criterion for ensuring the reliability of the scale is the minimum Cronbach $\alpha$ coefficient of 0.6 and a minimum total correlation coefficient of 0.3 . Following factors will be tested for convergence by using Exploratory Factor Analysis (EFA). The appropriate standards for EFA are the minimum Kaiser-Meyer-Olkin (KMO) coefficient of 0.5, Bartlett's test with a pvalue less than 0.05 , minimum explanation of $50 \%$, minimum Eigenvalue of 1 . Furthermore, to test the hypothesis, contribution of H1a, H1b, H2a, H2b, H3, H4a, H4b, H4c, H5, H6, H7a, H7b, $\mathrm{H} 8$, the regression analysis was used by looking at the magnitude number of $\mathrm{R}$ Square (Percentage of R Square). We used a linear regression analysis to analyze the correlation between pairs of variables and used a logistic regression analysis to estimate the presence or absence of Biology learning and teaching activities in career orientation for students. Data were analyzed by using a Statistical Package for Social Science (SPSS 20) software.

\section{RESULTS}

\subsection{The reliability of research model}

Analysis the reliability of the questionnaires' scales showed that Cronbach's $\alpha$ is higher than 0.6 (from 0.67 to 0.85 ), corrected item-total Correlation is higher than 0.3 (from 0.48 to 0.74 ), and cumulative of total variance explained is higher than 50\%. These data support the idea that the factors-measuring items are highly reliable to use.

\subsection{Statistical analysis of studied samples}

As shown in Table 3, the descriptive analysis of the findings in this study indicated that teachers used the student-led investigations in the highest frequency with a mean value of 3.09. And the next ones are teaching differentiation with a mean value of 3.08, teaching applications of science with a mean value of 2.9 , context-based approach with a mean value of 2.89 , respectively, in all science teaching approaches. 
International Journal of Education (IJE) Vol.6, No.4, December 2018

Table 2. Descriptive analysis

Item/factor (scale) Mean Std.Deviation

$\begin{array}{lll}\text { Students' science-related career aspiration }(1=Y) & 0.38 & 0.48\end{array}$

Teaching: project-based activities $(1-4) \quad 2.90 \quad 0.66$

Teaching: applications of science $(1-4) \quad 2.24 \quad 0.60$

Teaching: student-led investigations $(1-4) \quad 2.82 \quad 0.51$

$\begin{array}{lll}\text { Teaching of relevance of study and career } & 3.32 & 0.47\end{array}$

$\begin{array}{lll}\text { Students' subject interest }(1-4) & 3.39 & 0.42\end{array}$

$\begin{array}{lll}\text { Students' career awareness }(1-4) & 2.61 & 0.72\end{array}$

$\begin{array}{lll}\text { Students' utility of science (1-4) } & 3.33 & 0.41\end{array}$

$\begin{array}{lll}\text { Students' science self-efficacy (1-4) } & 2.20 & 0.58\end{array}$

Valid N (listwise) 345

In this research in Vietnam (Table 3), 38\% of students in this study had STEM-related career aspiration. Based on the mean value of sample we can see that students most frequently reported performing Biology learning activities that highlighted the 'relevance of study and career', and then 'project-based activities', 'student-led investigations' and 'context-based approach', respectively.

\subsection{Modeling teacher's STEM career orientation teaching}

Table 3. Correlations summary 


\begin{tabular}{|c|c|c|c|c|c|c|c|c|c|c|c|}
\hline & 1 & 2 & 3 & 4 & 5 & 6 & 7 & 8 & 9 \\
\hline 1. & Students ' STEM & $\begin{array}{l}\text { Pearson } \\
\text { Correlation }\end{array}$ & 1 & & & & & & & & \\
\hline & & Sig. (2-tailed) & & & & & & & & & \\
\hline \multirow[t]{2}{*}{2.} & Student's & $\begin{array}{l}\text { Pearson } \\
\text { Correlation }\end{array}$ & .413 & 1 & & & & & & & \\
\hline & subject interest & Sig. (2-tailed) & .000 & & & & & & & & \\
\hline \multirow[t]{2}{*}{3.} & $\begin{array}{l}\text { Teaching: } \\
\text { application of }\end{array}$ & $\begin{array}{l}\text { Pearson } \\
\text { Correlation }\end{array}$ & .298 & -.248 & 1 & & & & & & \\
\hline & science & Sig. (2-tailed) & .002 & .010 & & & & & & & \\
\hline \multirow[t]{2}{*}{4.} & $\begin{array}{l}\text { Teaching: } \\
\text { project-based }\end{array}$ & $\begin{array}{l}\text { Pearson } \\
\text { Correlation }\end{array}$ & -.113 & -.179 & .692 & 1 & & & & & \\
\hline & activities & Sig. (2-tailed) & .248 & .067 & .000 & & & & & & \\
\hline \multirow[t]{2}{*}{5.} & $\begin{array}{l}\text { Teaching: } \\
\text { student-led }\end{array}$ & $\begin{array}{l}\text { Pearson } \\
\text { Correlation }\end{array}$ & -.230 & -.254 & .552 & .629 & 1 & & & & \\
\hline & investigations & Sig. (2-tailed) & .018 & .009 & .000 & .000 & & & & & \\
\hline \multirow[t]{2}{*}{6.} & Student's self- & $\begin{array}{l}\text { Pearson } \\
\text { Correlation }\end{array}$ &.- .317 & -.384 & .218 & .190 & .367 & 1 & & & \\
\hline & efficac & Sig. (2-tailed) & .001 & .000 & .025 & .051 & .000 & & & & \\
\hline \multirow[t]{2}{*}{7.} & $\begin{array}{l}\text { Teaching } \\
\text { science }\end{array}$ & $\begin{array}{l}\text { Pearson } \\
\text { Correlation }\end{array}$ & .292 & .319 &.- .304 & -.187 & -.199 & -.323 & 1 & & \\
\hline & application & Sig. (2-tailed) & .002 & .001 & .002 & .055 & .041 & .001 & & & \\
\hline \multirow[t]{2}{*}{8.} & Teaching: & $\begin{array}{l}\text { Pearson } \\
\text { Correlation }\end{array}$ & .210 & .449 & -.325 & -.260 & -.327 & -.312 & .366 & 1 & \\
\hline & study and career & Sig. (2-tailed) & .030 & .000 & .001 & .007 & .001 & .001 & .000 & & \\
\hline \multirow[t]{2}{*}{9.} & \multirow{2}{*}{$\begin{array}{l}\text { Student's } \\
\text { awareness of } \\
\text { career }\end{array}$} & $\begin{array}{l}\text { Pearson } \\
\text { Correlation }\end{array}$ & -.273 & -.106 & .388 & .379 & .450 & .193 & -.199 & -.287 & 1 \\
\hline & & Sig. (2-tailed) & .005 & .280 & .000 & .000 & .000 & .047 & .041 & .003 & \\
\hline
\end{tabular}

Note: Pearson correlations coefficients are reported. Significant coefficients $(\mathrm{p}<0.05)$ are highlighted in bold.

The result showed that, there were correlative associations between the various teaching approaches ( 'project-based activities', 'teaching the applications of science', and 'student-led investigations', 'teaching the relevance of study and career') with student's awareness of career, student's self-efficacy, student's subject interest and students' STEM career orientation which were considered for Pearson correlations from 0.18 to 0.413 (Table 3). Moreover, students' STEM career aspiration strongly associated with students' subject interest with a Pearson correlation coefficient of 0.413 . It is also significantly associated with 'teaching the applications of science' and 'teaching the relevance of study and career' with a Pearson correlation coefficient of 0.292 and 0.21 respectively. In contrast, 'student-led investigations', 'student's self-efficacy' and 'student's awareness of career' negatively associated with students' STEM career orientation. However, the results also indicated that project-based teaching approaches had no effect on students' STEM career aspiration.

The results of the linear regression analysis were shown in figure 2 with the number of $\mathrm{R}$ Square was 0.52 and $p$-value $<0.05$.

The results of the hypothesis test $1 \mathrm{a}, 1 \mathrm{~b}(\mathrm{H} 1 \mathrm{a}, \mathrm{H} 1 \mathrm{~b})$ indicated that there were contributions of student-led investigations activities to student's career awareness and student's science self- 
efficacy. They were shown by Standardized Coefficients of 0.288 and 0.245 and p-value were $<0.05$.

Another interesting finding was that the results of hypothesis test $4(\mathrm{H} 4 \mathrm{a}, \mathrm{H} 4 \mathrm{~b}, \mathrm{H} 4 \mathrm{c})$ indicated that there were contributions of teaching the relevance of study and career to student's utility of science, student's science self-efficacy and student's subject interest at the research sites, shown by the Standardized Coefficients were $0.31,0.326$ and 0.216 and $p$-value were $<0.05$ (figure 2 ).

The result of hypothesis test $\mathrm{H} 2 \mathrm{a}$ revealed that there was a contribution of teaching the applications of to student's utility of science which was shown by the Standardized Coefficients was 0.232 and p-value $<0.05$. Furthermore, there was a contribution of student's utility of science to student's STEM career aspiration with Standardized Coefficients was 0.328 and pvalue $<0.05$

However, the result of hypothesis test $\mathrm{H} 2 \mathrm{~b}$ and test $3(\mathrm{H} 3)$ revealed that there were not contributions of teaching the applications of science and a project-based approach to student's science self-efficacy and student's subject interest. Similarly, there was not a contribution of student's science self-efficacy to students' STEM career aspiration.

An important finding showed that there were contributions of student's career awareness (hypothesis H6) and student's science self-efficacy (hypothesis H7b) to students' STEM career aspiration. They were shown by Standardized Coefficients was 0.198 and 0.232 and p-values $<0.05$.

The result of hypothesis test $8(\mathrm{H} 8)$ demonstrated that there was a contribution of student's subject interest to students' STEM career aspiration which was shown by the Standardized Coefficients was 0.325 and p-value $<0.05$.

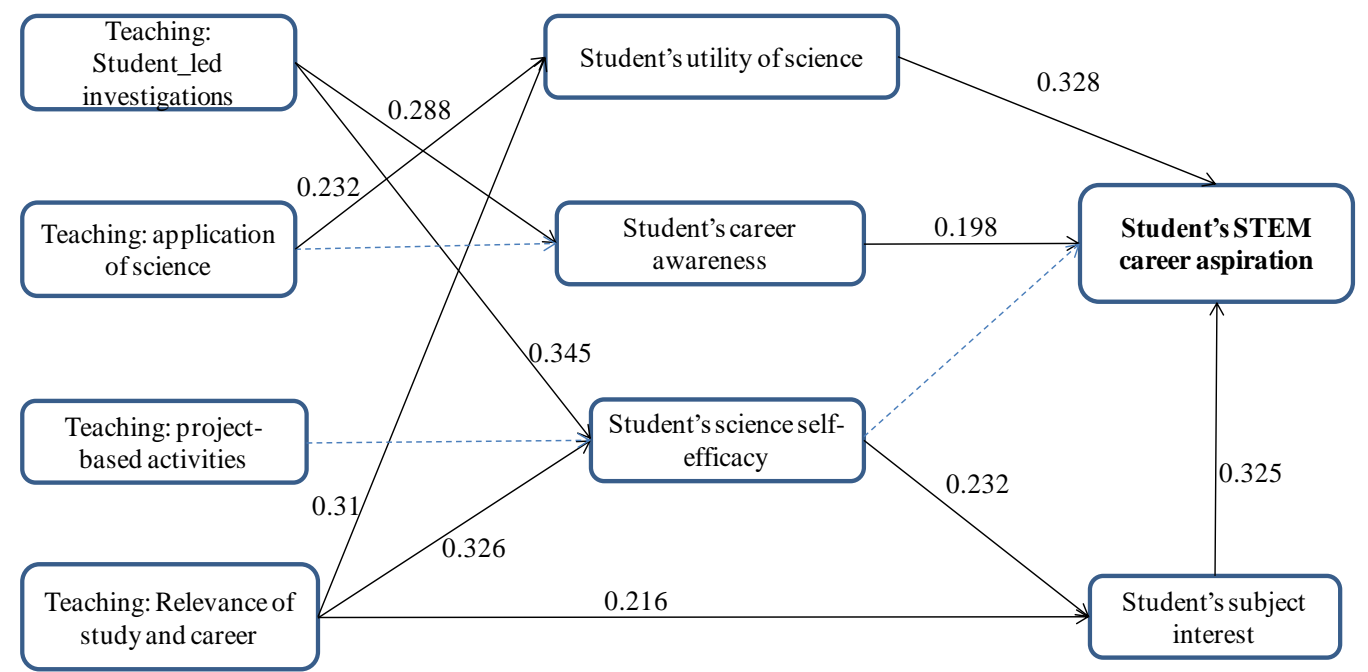

Figure 2. Summary of linear correlations between variables in the research model

Moreover, the result of predicting students' STEM career aspiration by using logistic regression statistic was indicated in table 4 with an overall percentage of $70.8 \%$. The model of predictor shown that only 'teaching the application of science' was the factor to consistently and positively 
associated with students' STEM career aspiration. It was shown by the number of R Square was 0.420 and $p$-value $<0.05$.

However, other teaching approaches such as student-led activities, project-based activities, students' utility of science had no effect on students' STEM career aspiration. Besides, students' science self-efficacy, the teaching of the relevance of study and career and students' career awareness were factors which associated negatively with students' STEM career aspiration.

Table 4. Summary of logistic regression of independent variables with students' STEM career aspiration

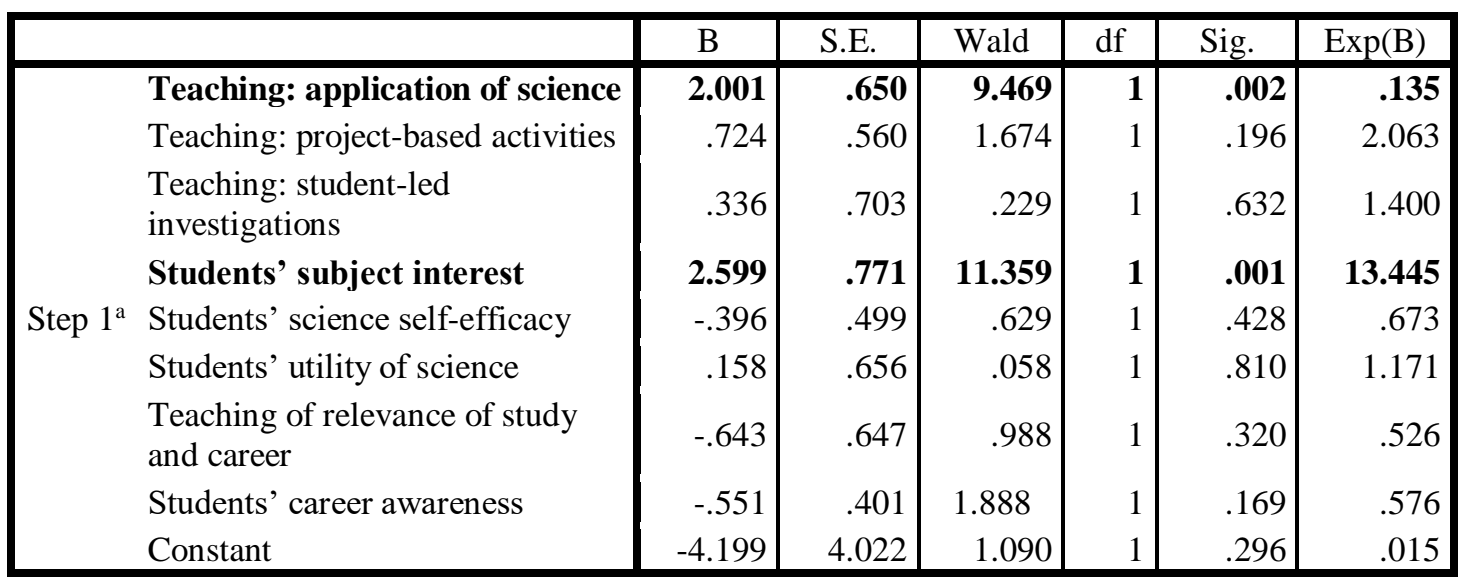

Note: Nagelkerke R Square : 0.420

\section{DISCUSSION}

The presented results highlighted the effects of Biology teaching approaches in STEM career orientation for high school students. The new significant insight for Biology teaching was that conveying the 'teaching applications of science' and 'teaching the relevance of study and career' were the measured teaching approaches to consistently and positively associate with students' STEM career aspiration accounting for the other teaching approaches.

Addressing the first research aim, from across the indicators of different frequencies of teaching approaches (organizing 'project-based activities', organizing 'student-led investigations', exploring 'the relevance of study and career' and conveying the 'applications of science'), conveying the 'applications of science' and exploring 'the relevance of study and career' were approaches to consistently and positively associate with theorised antecedents when accounting for the other teaching approaches.

The results supported the hypothesis that explaining the wider context or applications of science would associate with students' STEM career aspiration which accordingly coheres with implications from existing research (Savelsbergh et al., 2016; Straw and Macleod, 2015; Sheldrake, 2017). However, the results did not clearly support the hypothesis that project-based approaches (assumed to be identified through the 'hands-on/practical activities' and 'student-led investigations' indicators) would associate with high efficiency (Savelsbergh et al., 2016). Although student-led investigations indirectly associated to students' STEM career aspiration, it 
affected student's career awareness and student's science self-efficacy which positively contribute to associated to students' STEM career aspiration. These findings might explain the reality that Biology teachers in Vietnamese schools have not used frequently and effectively the project-based activities and student-led investigation to orient STEM career for students yet.

The analysis considered indicators of teaching approaches that have variously been explored and applied within science education. Applying 'project-based activities' has often been assumed to reflect the empirical nature of science (Millar,1998). Practical work and 'student-led investigations' both occur within wider ideas of inquiry-based learning of science, which again aim to reflect overall processes of scientific inquiry (Furtak et al., 2012). Alternately, conveying the 'applications of science' does not necessarily require an underlying assumption that students must learn by doing what scientists do. Conveying the 'applications of science' may potentially link with wider teaching/learning approaches where students learn scientific skills and ideas specifically through considering applied contexts but do not necessarily imply or require this (Ekung \& Okonkwo,2015; Bennett et al., 2007). Conveying the 'applications of science' could supplement any other teaching approaches, practical or otherwise.

According to the result of predicting students' STEM career aspiration by using logistic regression statistic in case of Vietnam, 'teaching applications of science' was the teaching factor to consistently and positively associated with STEM career aspiration.

However, Biology teachers should organize project-based activities and teaching applications of science in order to career orientation because these approaches were empirically verified to associate with career interest (Abrahams \& Reiss, 2012; Furtak, Seidel, Iverson, \& Briggs, 2012).

\section{CONCLUSION}

Analysis of Biology learning and teaching in Vietnam highlighted that teaching the 'applications of science' and exploring 'the relevance of study and career' were measured teaching approaches to consistently and positively associate with high school students' STEM career aspiration, accounting for other teaching approaches. Additionally, in this study, the 'student-led investigations' indirectly associated with students' STEM career aspiration by affecting on affected student's career awareness and student's science self-efficacy. However, the projectbased approach had no obvious effect on students' STEM career aspiration.

Teaching the application of science and teaching the relevance of study and career consistently had the strongest positive association with their STEM-related career orientation teaching, in Vietnam, accounting for extensive arrays of other factors.

Overall, these patterns of results suggested that conveying the wider relevance of science to everyday life and to wider contexts may help foster students' aspirations towards STEM careers.

\section{REFERENCES}

[1] Abrahams, I., \& Millar, R. (2008). Does Practical Work Really Work? A study of the effectiveness of practical work as a teaching and learning method in school science. International Journal of Science Education, 30(14), 1945-1969. http://dx.doi.org/10.1080/09500690701749305. 
International Journal of Education (IJE) Vol.6, No.4, December 2018

[2] Abrahams, I., \& Reiss, M. J.(2012). Practical work: Its effectiveness in primary and secondary schools in England. Journal of Research in Science Teaching, 49(8), 1035-1055. http://dx.doi.org/10.1002/tea.21036.

[3] Archer, L., Dawson, E., DeWitt, J., Seakins, A., \& Wong, B. (2015). Science capital: A conceptual, methodological, and empirical argument for extending Bourdieusian notions of capital beyond the arts. Journal of Research in Science Teaching, 52(7), 922-948. http://dx.doi.org/10.1002/tea.21227.

[4] Bernacki, M., Nokes-Malach, T., Richey, J. E., \& Belenky, D. (2016). Science diaries: A brief writing intervention to improve motivation to learn science. Educational Psychology, 36(1), 26-46. http://dx.doi.org/10.1080/01443410.2014.895293.

[5] Bennett, J., Lubben, F., \& Hogarth, S. (2007). Bringing science to life: A synthesis of the research evidence on the effects of context-based and STS approaches to science teaching. Science Education, 91(3), 347-370. http://dx.doi.org/10.1002/sce.20186.

[6] Claussen, S., \& Osborne, J. (2013). Bourdieu's notion of cultural capital and its implications for the science curriculum. Science Education, 97(1), 58-79. http://dx.doi. org/10.1002/sce.21040.

[7] Dano-Hinosolango, M. A. (2013). Learner-centered teaching: the students' level of learning skills and strategies. International Journal of Education (IJE), Vol. 1, No. 1, December 2013. https://airccse.com/ije/papers/1113ije04.pdf

[8] Ekung, S. \& Okonkwo, E. (2015). Trend in influences on career choice in quantity surveying and its implications. International Journal of Education (IJE), Vol. 3, No. 1, March 2015. https://airccse.com/ije/papers/3115ije01.pdf

[9] Furtak, E. M., Seidel, T., Iverson, H., \& Briggs, D. (2012). Experimental and quasi-experimental studies of inquiry-based science teaching: A meta-analysis. Review of Educational Research, 82(3), 300-329. http://dx.doi.org/10.3102/0034654312457206.

[10] Harackiewicz, J., Rozek, C., Hulleman, C., \& Hyde, J.(2012). Helping parents to motivate adolescents in mathematics and science: An experimental test of a utility value intervention. Psychological Science, 23(8), 898-906. http://dx.doi.org/10.1177/0956797611435530.

[11] OECD (2015). Universal basic skills: What countries stand to gain Paris: OECD Publishing. http://dx.doi.org/10.1787/9789264234833-en

[12] Ornstein (2006). The Frequency of Hands-On Experimentation and Student Attitudes toward Science: A Statistically Significant Relation. Journal of Science Education and Technology Vol. 15, No. 3, October 2006

[13] Rosenzweig, E., \& Wigfield, A. (2016). STEM motivation interventions for adolescents: A promising start, but further to go. Educational Psychologist, 51(2), 146-163. http://dx.doi.org/10.1080/00461520.2016.1154792

[14] Sheldrake, R., Mujtaba, T., Reiss, M. (2017). Science teaching and students' attitudes and aspirations: The importance of conveying the applications and relevance of science. International Journal of Educational Research $85167-183$

[15] Stake, J.E., \& Mares, K.R. (2001). Science Enrichment Programs for Gifted High School Girls and Boys: Predictors of Program Impact on Science Confidence and Motivation. Journal of research in science teaching Vol. 38. No.10, pp $1065-1088$ 
[16] Subotnik, R.F., Tai, R.H., Rickoff, R., and Almarode, J. (2010). Specialized public high schools of science, mathematics, and technology and the STEM pipeline: what do we know now and what will we know in 5 years? Roeper Review, 32(1), 7-16

\section{Authors}

Coresponding author: Ho Thi Hong Van is a $\mathrm{PhD}$ student and an educational researcher, currently working for the Vietnam National Institute of Educational Sciences, Hanoi, Vietnam. Her research interests include curriculum development, teaching and learning activities, teacher's professional development.

Le Ngoc Hoan is a PhD in Biology of Ulsan University, Pusan, Korea. At present, he is a lecturer in the Faculty of Biology, Hanoi National University of Education, Hanoi, Vietnam. His researches include teaching and learning activities, teacher's professional development.

Dinh Quang Bao is a Professor in the Hanoi National University of Education, Hanoi, Vietnam and he is also a manager of Renovation of General Education Project in Vietnam. Moreover, he was the Director of Hanoi National University of Education. His research interests include curriculum development, teaching and learning activities, teacher training, teacher's professional development.

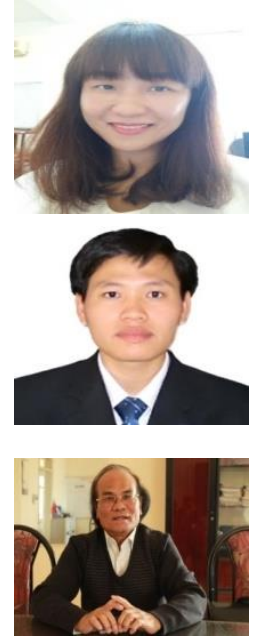

